\title{
Daily milk intake improves vitamin B-12 status in young vegetarian Indians: an intervention trial
}

\author{
Sadanand Naik ${ }^{1 *}$, Vijayshri Bhide ${ }^{1}$, Ashish Babhulkar ${ }^{1}$, Namita Mahalle ${ }^{1}$ Sonali Parab ${ }^{1}$, Ravi Thakre ${ }^{2}$ \\ and Mohan Kulkarni ${ }^{3}$
}

\begin{abstract}
Background: Asymptomatic Indian lacto vegetarians, who make up more than half of the Indian population in different geographic regions, have distinctly low vitamin B-12 concentrations than non- vegetarians. Vegetarians consume milk but it seems that the amount is not enough to improve vitamin B-12 status or vitamin B-12 concentration in milk itself may be low. The aim of this study was to determine if daily milk consumption can improve vitamin B-12 status.

Methods: Fifteen male and 36 female, young healthy post-graduate volunteers participated. Blood from ten participants (4 males and 6 females) was collected (day-1). They continued their regular diet for next fourteen days and on day-15, blood of all 51 participants was collected, plasma vitamin B-12 concentration was measured and were divided into two groups; Normal (vitamin B-12 >148 pmol/L, $n=22)$ and Vitamin B-12 deficient $(<148 \mathrm{pmol} / \mathrm{L}$, $\mathrm{n}=29)$, the remaining plasma was stored. All participants consumed $600 \mathrm{ml}$. of non-enriched buffalo milk $(200 \times 3)$ during the day along with their usual diet. Next day blood was collected for plasma holotranscobalamin II measurement. Subjects from deficient group continued to drink $400 \mathrm{ml}$ of milk daily for next 14 days and blood was collected on day-30. Plasma holotranscoabalamin II (day-1, 15, 16, 30), vitamin B-12, folate, total homocysteine, creatinine and hematoloical parameters (day-1, 15, 30), and milk vitamin B-12 concentrations (day-15, 16, 30) were measured.
\end{abstract}

Results: Fifty seven per cent of the participants were vitamin B-12 deficient and 65\% were hyperhomocysteinemic. No significant difference in biomarkers was observed when there was no intervention. Plasma holotranscobalamin II concentration increased from 19.6 to $22.27 \mathrm{pmol} / \mathrm{L}(\mathrm{p}<0.0001) 24 \mathrm{hrs}$ after milk load in the whole group. Plasma vitamin B-12 increased from 92.5 to $122 \mathrm{pmol} / \mathrm{L}$ and tHcy concentrations decreased from 31.9 to $24.9 \mu \mathrm{mol} / \mathrm{L}$ ( $p<0.0001$ for both) 14 days after regular milk intake in vitamin B-12 deficient subjects.

Conclusions: Regular intake of milk improved vitamin B-12 status of vitamin B-12 deficient vegetarians indicating a potential dietary strategy to improve the vitamin status.

Keywords: Milk, Vitamin B-12 status, Holotranscobalamin II, Vitamin B-12, Folate, Total homocysteine, Cobalamin

\section{Background}

Dietary reference intake of vitamin B-12 was defined as the amount required to prevent the overt vitamin B-12 deficiency that causes megaloblastic anemia and to maintain plasma concentrations above $148 \mathrm{pmol} / \mathrm{L}$ [1]. The recommended dietary allowance (RDA) of vitamin B-12 for adults in India is $1.0 \mu \mathrm{g} /$ day [2], whereas in

\footnotetext{
*Correspondence: sadu_naik@rediffmail.com

'Department of Clinical Biochemistry \& Orthopedics, Deenanath Mangeshkar Hospital \& Research Centre, Erandvane, Pune, India

Full list of author information is available at the end of the article
}

USA it is $2.4 \mu \mathrm{g} /$ day [3]. Vitamin B-12 intake by Indians derives from natural food products, i.e. dairy products viz. milk, yogurt, and cheese/butter, tea/coffee with milk or from vitamin B-12 supplements. The relation between dietary intake and vitamin B-12 status has been studied in different populations with conflicting results. Howard et al [4] concluded that high frequency of mildly abnormal cobalamin status in the elderly was not due to poor intake of cobalamin, whereas, Framingham Offspring [5] and Danish Study [6] showed significant associations between dietary intake of vitamin B-12 and

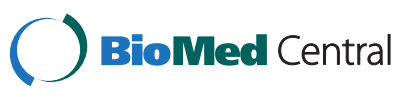


plasma concentrations. In a large population-based study, Vogiatzoglou et al [7] found a significant association between total daily dietary intake of vitamin B-12 and plasma vitamin B-12 concentrations. They further stated that daily dietary intake of $6-10 \mu \mathrm{g}$ of vitamin B-12 ensured the maximum plasma vitamin B-12 concentration in persons with adequate vitamin B-12 absorption suggesting that the current RDA of $2.4 \mu \mathrm{g} /$ day is also insufficient. The Framingham Offspring Study [5] first observed that vitamin B-12 from milk was better absorbed than meat. Wokes et al [8] systematically compared a group of US, Dutch and British vegans with non-vegetarians from those same countries and found that many of the vegans had significantly lower vitamin B-12 concentrations than did nonvegetarians. Dhopeshwarkar et al [9] showed that asymptomatic Indian lacto vegetarians, who make up more than half of the Indian population, have distinctly low vitamin B-12 concentrations than non-vegetarians which was confirmed by studies from different geographic regions of India [10-14]. Two main etiologic factors play a role in developing vitamin B-12 deficiency; inadequate dietary intake and/or vitamin B-12 mal-absorption.

Bhat et al [15] have used the rise in plasma holotranscobalamin II ( holo-TC) concentrations with a smaller dose of cyanocobalamin $(6 \mu \mathrm{g})$ in vitamin B-12 deficient Indians as a marker of absorption. The increase in plasma holo-TC concentration after vitamin B-12 load provided experimental evidence that the increase was due to recent vitamin B-12 absorption. The deficiency of vitamin B-12 has been associated with diverse disorders throughout the life span, from birth defects such as shunted growth, neural tube defects, anemia to hyperhomocysteinemia and neuro-cognitive disorders in adulthood [16-18]. Recently, low plasma vitamin B-12 concentrations in pregnancy have been shown to be associated with diminished neuro-cognitive performance in offspring [19]. Several morbidities may be associated with low-normal vitamin B-12 status (< $148 \mathrm{pmol} / \mathrm{L})$. Therefore, it is important to establish whether dietary intervention by the available natural source can improve vitamin B-12 status in Indian vegetarian population and protect from diverse disorders.

The option of increasing overall vitamin B-12 status of deficient population is either fortification or targeted dietary recommendation. The present study measured the effects of supplementation with $600 \mathrm{ml}$ of skimmed buffalo milk not enriched with vitamin B-12, during the day on circulating holo-TC concentration. It also measured the supplementary effects with $400 \mathrm{ml}$ of nonenriched milk daily for 14 days on vitamin B-12 status by measuring the changes in plasma holo-TC, vitamin B-12 and total homocysteine (Hcy) concentrations.

\section{Subjects and methods Participants}

Young, healthy and post graduate students and staff members of Deenanath Mangeshkar Hospital were invited to visit the laboratory. They were told about the high prevalence of vitamin B-12 deficiency in Indian vegetarians and requested to participate in the intervention study. Pregnant women, non-vegetarians and lactose intolerant subjects were requested not to participate. Fifty one volunteers consented to participate in the study (15 males and 36 females, day-0). They had no clinical symptoms of vitamin B-12 deficiency and were not taking vitamin B-12 supplementation or any drugs known to influence vitamin B-12 absorption. All were vegetarians, non-smokers and none consumed alcohol. Their milk intake was not more than 2 cups (120-140 mL) per day. After recruitment, each participant was instructed to report to the laboratory every day and give information about their regular timely milk intake.

They were also instructed to not to change their life style during the study period.

\section{Study design \\ Intra-individual variation}

Ten participants were selected for evaluating intraindividual variation in the measurement of plasma vitamin B-12, holo-TC, folate and tHcy concentrations. They were instructed to not to change their life-style during the study period. Their fasting blood was collected in EDTA vacutainer on day-1 and day-15.

\section{4-hrs. milk load test}

Fasting blood of other 41 healthy participants was collected in EDTA vacutainers on day-15. A portion of blood was processed for hematological parameters within 30 minutes of collection and the rest was centrifuged at $1500 \mathrm{rpm}$ for 20 minutes and the plasma was separated and distributed in four storage vials and stored at $-20^{\circ} \mathrm{C}$. All of them (51 participants) were instructed to drink $3 \times 200 \mathrm{ml}$ of milk along with their usual diet during the day (in the morning after breakfast, evening at 4 p.m. and at night after dinner) and come to the Laboratory next morning-9 am. On day-16, $10 \mathrm{ml}$. of fasting blood was collected and the separated plasma was stored as above (Figure 1: Flow sheet).

\section{Effect of daily milk intake on vitamin B-12 status}

Plasma (day-15) vitamin B-12 was measured and the participants were divided into two groups; normal group (plasma vitamin B-12>148 pmol/L, $\mathrm{n}=22$ ) and the deficient group $(<148 \mathrm{pmol} / \mathrm{L}, \mathrm{n}=29)$. The participants from the deficient group were instructed to drink $2 \times 200 \mathrm{ml}$ of milk (in the morning after breakfast and after dinner) every day along with their usual diet for the next 14 days 


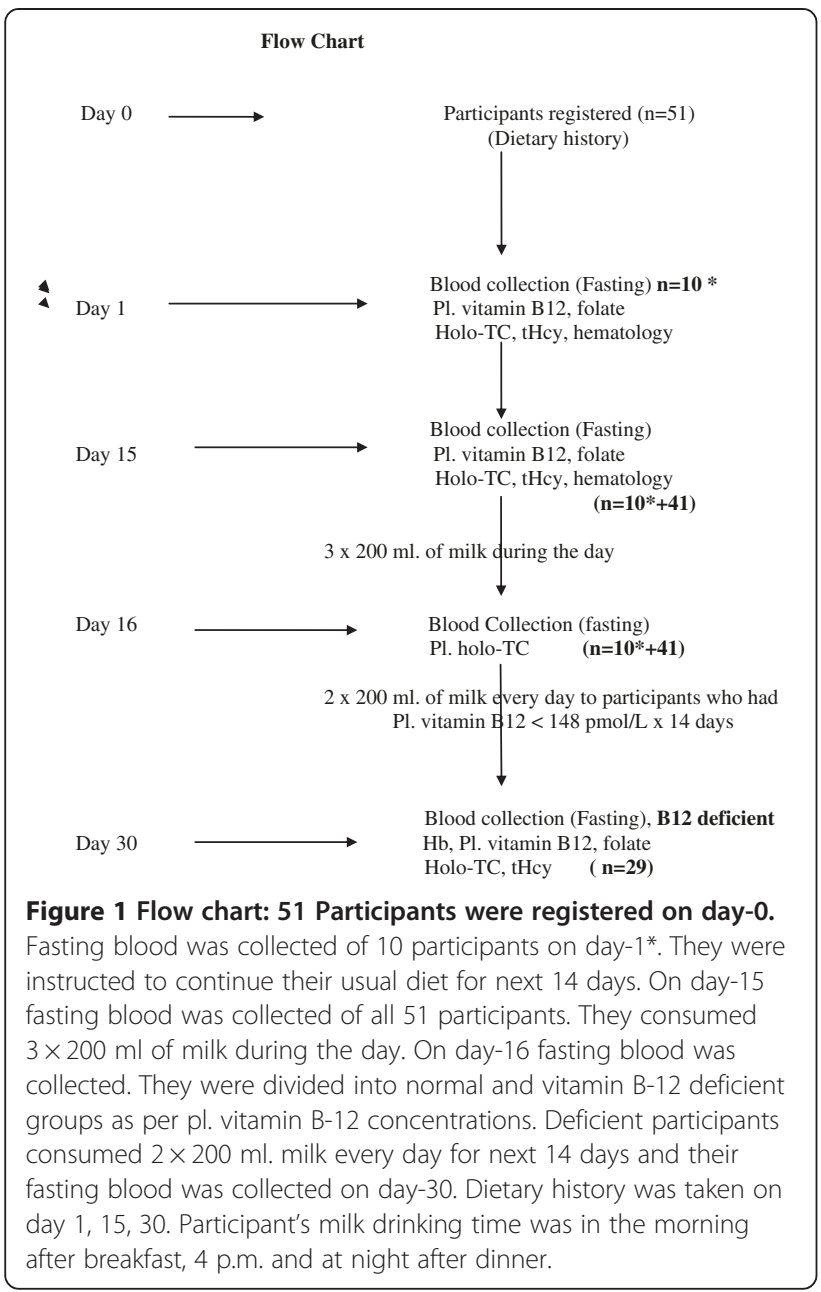

and come to the laboratory on day- $30.10 \mathrm{ml}$. of fasting blood was collected and processed as above. None of the participants neither failed to drink milk nor omitted (reported to the investigator on day-16, day-17 and then every day morning till day-30). There was $100 \%$ compliance in milk consumption from the participants. They provided the sample (about $6 \mathrm{ml}$ ) of milk consumed for measuring vitamin B-12 concentrations on day 15, 16 and 30 (Figure 1. Flow sheet).

\section{Experimental procedure}

Hematological parameters were measured on 5 part differential cell counter (Sysmex, Cobe, Japan). Plasma holo-TC concentration was measured using microparticle enzyme immunoassay [20]. Microparticle enzyme intrinsic factor assay was used for the quantitative determination of plasma vitamin B-12. Plasma folate and tHcy were measured by fluorescent polarization immune assay technique. Milk samples were incubated with denaturant $(0.8 \mathrm{~N}$ sodium hydroxide solution with $0.005 \%$ potassium cyanide) in 9:1 proportion for 15 minutes at $56^{\circ} \mathrm{C}$, centrifuged and processed for vitamin B-12 estimation after diluting with saline (1:10) as mentioned for plasma. All the milk samples were processed for vitamin B-12 measurements on the same day of collection. These biomarkers were measured on Axsym System (Abbott Laboratories, IL, USA). Plasma creatinine was measured on Daytona (Randox, U.K.) using alkaline picrate method [21]. The intra- and inter-assay coefficients of variations were less than $6.2 \%$ for hematological and biochemical (vitamin B-12, folate, holo TC, creatinine and tHcy) parameters.

\section{Dietary intake data}

The participants were examined for gross clinical signs of protein-energy under-nutrition and vitamin deficiencies (vitamin A, B-complex, C and D). Staff enquired about upper or lower gastro intestinal disease symptoms and also about milk intolerance. They were interviewed regarding eating habits and health status before enrolling. They consumed their habitual diet throughout the study. Their dietary history ( $24 \mathrm{hr}$ recall) was taken by trained and experienced personnel at each visit (day-1, day-15, day-30). $24 \mathrm{hr}$. diet recall questionnaire was administered to record the portion size and quantity of consumption of different foods which were rich in micronutrients at both visits [22]. Foods rich in vitamin B-12 and folate were selected and grouped into four groups; milk and milk containing beverages, tea/coffee with milk, green leafy vegetables and other vegetables. Vitamin B-12 and folate intake were calculated using Dietsoft [23].

\section{Ethics statement}

The study was approved by the ethical committee of Deenanath Mangeshkar Hospital \& Research Centre, Pune. Written informed consent was obtained from all participants before enrolling into the study.

\section{Dietary supplement}

Vitamin B-12 concentrations in the milk samples from 12 different sources of non-enriched of milk (buffalo) supply being consumed by the Pune population were measured on three occasions (day-15, 16, 30).

\section{Definitions}

Folate and vitamin B-12 deficiency were defined as plasma concentrations $<2 \mathrm{ng} / \mathrm{ml}[24]$ and $<148 \mathrm{pmol} / \mathrm{L}$ [24] respectively, hyperhomocysteinemia as plasma tHcy concentrations $>15 \mu \mathrm{mol} / \mathrm{L}$ [25], low holo-TC concentration as $<35 \mathrm{pmol} / \mathrm{L}$ [26], anemia as a hemoglobin concentration $<120 \mathrm{~g} / \mathrm{L}$ in females and $<130 \mathrm{~g} / \mathrm{L}$ in males and macrocytosis as mean corpuscular volume $>100 \mathrm{fL}$ [27].

\section{Statistical analysis}

Intra individual variation was calculated from the estimation of variance by ANOVA from the measurements of 
the analytes from the two samples obtained from day-1 and day- 15 before intervention.

The data is presented as median with $25^{\text {th }}$ and $75^{\text {th }}$ percentiles. Differences between groups were tested using Wilcoxon's Signed rank matched pair test, a non parametric test, for paired analysis. Association was measured using Pearson Correlation Coefficient. Relative percentage change was calculated with respect to presupplementation value. The analysis was performed using SPSS (version 12.0, Chicago, USA).

\section{Results}

The vitamin B-12 concentration in milk supplied by the sources of Pune supply is shown in Table 1; ranges from 2.50 to $3.85 \mu \mathrm{g} / \mathrm{L}$. There was no significant variation in vitamin B-12 content of the milk at different times. Fifty one subjects ( 15 male and 36 female) participated in the study. Evaluating 24-hr recall questionnaire, male subjects were consuming $1.1 \mu \mathrm{g}$ of vitamin B-12 per day while females $1.35 \mu \mathrm{g}$ per day. Main dietary sources of vitamin B-12 are listed in Table 2. Milk represented the predominant source of vitamin B-12 followed by yogurt. Tea/coffee with milk also contributed to some extent in these participants.

Vitamin B-12 intake was lower in deficient group than the normal group $(\mathrm{p}=0.02)$. Vitamin $\mathrm{B}-12$ intake was directly related to plasma vitamin B-12 and holo-TC $(r=0.520$ and 0.270 respectively, $p=0.001$ for both $)$ and inversely to tHcy concentrations $(\mathrm{r}=-0.430, \mathrm{p}=0.001)$. The relation was similar in both sexes. There was no folate deficiency and the plasma folate concentrations were

Table 1 Vitamin B-12 concentration in the milk (Sources of Pune supply)

\begin{tabular}{|c|c|c|c|}
\hline \multirow[t]{2}{*}{ Milk source } & \multicolumn{3}{|c|}{ Vitamin B-12 $(\mu \mathrm{g} / \mathrm{L})$} \\
\hline & Day-15 & Day-16 & Day-30 \\
\hline Chitale $(n=30)$ & $3.85(3.7,4.1)$ & $4.0(3.7,4.2)$ & $\begin{array}{l}3.9(3.7,4.0) \\
n=8\end{array}$ \\
\hline Rajhans $(\mathrm{n}=3)$ & $2.90,3.1,2.9$ & $2.8,2.8,2.9$ & $3.0,3.2,3.3$ \\
\hline Katraj dairy $(n=3)$ & $3.0,3.2,3.0$ & $3.2,3.0,3.1$ & $3.0,2.8,3.2$ \\
\hline Godavari $(n=3)$ & $2.95,3.0 .3 .1$ & $3.3,3.2,3.0$ & $3.3,3.0,3.3$ \\
\hline Gowardhan $(n=1)$ & 2.90 & 3.0 & 3.2 \\
\hline Bhaiya Rasta Peth $(n=1)$ & 2.50 & 2.8 & 2.6 \\
\hline Sane dairy $(n=3)$ & $2.7,2.90,3.0$ & $3.1,3.3,3.0$ & 3.2 \\
\hline Swarkar dairy $(\mathrm{n}=3)$ & $2.80,3.1,3.0$ & $3.0,3.3,3.1$ & $2.8,3.2,3.1$ \\
\hline Amol milk $(n=1)$ & 3.05 & 3.0 & 3.2 \\
\hline Baiya - Mundhwa $(n=3)$ & $2.60,2.8,2.8$ & $3.0,2.8,3.0$ & $3.0,3.1,2.8$ \\
\hline Aarey milk $(n=1)$ & 3.2 & 3.1 & 3.2 \\
\hline Someshwar dairy $(n=1)$ & .8 & 3.0 & 3.0 \\
\hline
\end{tabular}

The vitamin B-12 contents were similar throughout the study. Median $\left(25^{\text {th }}, 75^{\text {th }}\right.$ centile).

$\mathrm{n}=$ number of participants consuming milk. Values are the vitamin B-12 concn. in the milk.
Table 2 Contribution of vitamin B-12 from different food groups in the participants

\begin{tabular}{lll}
\hline Food intake & Quantity/d & $\begin{array}{l}\text { Vitamin B-12 } \\
\text { intake }(\boldsymbol{\mu ~ g / d})\end{array}$ \\
\hline $\begin{array}{l}\text { Dairy products } \\
\text { Tea/coffee - with } \\
\text { milk }(\mathrm{g} / \mathrm{d})\end{array}$ & $40(30,55)$ & $0.18(0.10,0.22)$ \\
Milk (ml/d) & $140(120,160)$ & $0.56(0.5,1.03)$ \\
Yogurt (g/d) & $70(45,120)$ & $0.15(0.06,0.3)$ \\
Cheese/butter $(\mathrm{g} / \mathrm{d})$ & $10(9,20)$ & $0.1(0.08,0.18)$ \\
\hline
\end{tabular}

Median ( $25^{\text {th }}$ centile, 75 th centile).

similar in both the groups. Calorie, protein and fat intake were also similar and within the limits of Indian Council of Medical Research recommendation [28] (Table 3).

The intra individual variation for holo-TC, vitamin B-12, folate and tHcy were less than $6.2 \%$ for all, when there was no intervention in their routine life style (Table 4). There was no significant difference in vitamin B-12 intake at different times (Table 1).

Hemoglobin, mean corpuscular volume, plasma creatinine and tHcy were significantly higher in males $(\mathrm{p}<0.001$ for all). Plasma vitamin B-12 and holo-TC concentrations were significantly higher in females ( $\mathrm{p}<0.001 \mathrm{for}$ both).

Table 5 compares the extent of increase in plasma holoTC concentrations $24 \mathrm{hrs}$ after the milk load $(3 \times 200 \mathrm{ml})$. None of the participants complained of any sort of discomfort and none suffered from diarrhea. The increase in plasma holo-TC concentration $24 \mathrm{hrs}$ after $600 \mathrm{ml}$ milk load, the median (range) increase as (\%age and absolute), was $25.8(0-110 \%)$ and $4.2(0-16.4) \mathrm{pmol} / \mathrm{L}(\mathrm{p}<0.01) .1 / 4^{\text {th }}$ of the participants showed less than $3.0 \mathrm{pmol} / \mathrm{L}(12.5 \%)$ increase, half showed more than $26 \%$ and one fourth showed more than $43 \%$ increase. The participants showing less than $12.5 \%$ increase can be labeled as poor absorbers. Percentage increase in plasma holo-TC concentration was independent of basal holo-TC concentration (Figure 2). The increase in plasma holo-TC concentration 15 days after $400 \mathrm{ml}$ milk intake every day, the median (range) increase as (\%age and absolute), was 35.1 (5.1-201\%) and 5.0 (1-25.6 pmol/L). Similarly the decrease in plasma tHcy concentration was $9.7(0.7-49.3 \%)$ and $6.9(0.5-17 \mu \mathrm{mol} / \mathrm{L})$ respectively in vitamin B-12 deficient participants $(\mathrm{p}<$ 0.0001 for both). The significance was similar in both sexes. We also divided the participants by the observed median holo-TC concentration $(22.7 \mathrm{pmol} / \mathrm{L})$ and by $<35>\mathrm{pmol} / \mathrm{L}$ (reference cutoff). Both interpret the significant increase in plasma holo-TC $24 \mathrm{hr}$ after milk load (Tables 6, 7).

Holo-TC: vitamin B-12 ratio. [Median $\left(25^{\text {th }}, 75 \%\right.$ le)] on day-15 of all participants was $0.11(0.08,0.16)$. Normal participants showed $0.08(0.07,0.12)$ and deficient showed $0.14(0.0 .09,0.17)$ on day- 15 and $0.13(0.010,0.18)$ on day 30. Deficient participants showed increased plasma holoTC but not significant. 
Table 3 Dietary intake (24-hr recall) and basic biochemistry of the participants (normal \& deficient)

\begin{tabular}{|c|c|c|c|c|}
\hline & All $(n=51)$ & Normal $(n=22)$ & Deficient $(n=29)$ & $p$ value \\
\hline Age (years) & $27.6(26,30)$ & $29.0(27-31.0)$ & $30.6(28.5-32)$ & ns \\
\hline Male/female & $14 / 37$ & $4 / 18$ & $10 / 19$ & \\
\hline Energy intake (calorie)/d & $2240(2080,2280)$ & $2390(2220,2480)$ & $2200(2080,2270)$ & ns \\
\hline Protein intake $(\mathrm{g}) / \mathrm{d}$ & $62(52,80)$ & $58(50,82)$ & $64(55,80)$ & ns \\
\hline Fat $(\mathrm{g} / \mathrm{d})$ & $45(38,50)$ & $44(35,50)$ & $43(37,55)$ & ns \\
\hline \multirow[t]{2}{*}{ Vitamin B-12 intake ( $\mu$ g/day) } & 1.20 & 1.65 & 0.65 & $<0.02$ \\
\hline & $(0.75,1.50)$ & $(1.4,1.85)$ & $(0.50,0.90)$ & \\
\hline Folate intake ( $\mu \mathrm{g} /$ day) & $355(320,400)$ & $350.6(310.4,415.4)$ & $355.6(318.2,425.4)$ & ns \\
\hline Hemoglobin (g/L) & $127(117,136)$ & $124(114,130)$ & $128(123,135)$ & ns \\
\hline Anemia\% & 14 & 14 & 14 & \\
\hline Mean corpuscular volume (fL) & $84.0(81.0,90.5)$ & $80.5(75.0,85.0)$ & $84.3(82.2,90.4)$ & ns \\
\hline Plasma creatinine (mg/dL) & $1.0(0.9,1.1)$ & $0.9(0.8,1.1)$ & $1.0(0.9,1.1)$ & ns \\
\hline $\begin{array}{l}\text { Plasma vitamin B-12* } \\
\text { (pmol/L) }\end{array}$ & $130(98,217)$ & $244(187,306)$ & $92.8(71,117)$ & $<0.0001$ \\
\hline Plasma holo-TC $(\mathrm{pmol} / \mathrm{L})^{*}$ & $19.6(13.1-31.1)$ & $27.7(19.8,42.5)$ & $14.4(10.82,19.75)$ & $<0.0001$ \\
\hline Plasma folate $(\mathrm{ng} / \mathrm{mL})$ & $6.24(4.2,14.90)$ & $6.6(4.0,15.2)$ & $5.6(4.6,12.8)$ & ns \\
\hline Plasma tHcy ${ }^{* *}(\mu \mathrm{mol} / \mathrm{L})$ & $21.1(12.7,32.7)$ & $11.9(10.4,15.0)$ & $31.9(22.6,54.0)$ & $<0.001$ \\
\hline
\end{tabular}

Plasma holo-TC concentration did not rise after milk load in 4 normal and 2 deficient subjects. The basal plasma holo-TC concentrations were more than 45 $\mathrm{pmol} / \mathrm{L}$ and tHcy less than $12.5 \mu \mathrm{mol} / \mathrm{L}$ in the normal subjects in whom there was no rise in holo-TC concentrations. The two vitamin B-12 deficient participants did not respond to the $24 \mathrm{hr}$ milk intake. However, their plasma vitamin B-12 (50, $105 \mathrm{pmol} / \mathrm{L})$ increased to $(60,116)$, holo-TC $(13.1,19.4 \mathrm{pmol} / \mathrm{L})$ increased to $(14.9$, 21.5) and tHcy $(58.7,32.8 \mu \mathrm{mol} / \mathrm{L})$ decreased to (53.6, 28.1 ) respectively after 14 days of regular milk intake.
There was no significant difference in hemoglobin, MCV, plasma creatinine and folate concentrations in vitamin B-12 deficient participants 14 days after regular intake of milk, whereas, the increase in plasma vitamin B-12, holo$\mathrm{TC}$ and the decrease in plasma tHcy concentration was significant ( $\mathrm{p}<0.0001$ for all), Table 4 . There was no gender difference in the improvement of vitamin B-12 status.

Basal hemoglobin was not associated with circulating vitamin B-12 concentration. However, mean corpuscular volume was inversely related to plasma vitamin B-12. Intake of calorie, carbohydrates, fats and proteins did

Table 4 Effect of regular milk intake (14 days) on biomarkers

\begin{tabular}{|c|c|c|c|c|c|}
\hline \multirow{3}{*}{$\begin{array}{l}\text { Milk intake } 400 \mathrm{ml} \\
\text { Every day }\end{array}$} & \multicolumn{2}{|l|}{ Deficient group } & \multirow{3}{*}{ p value } & \multicolumn{2}{|c|}{ No intervention group $n=10$ (ns- for all) } \\
\hline & \multicolumn{2}{|l|}{$n=29$} & & & \\
\hline & Day-15 & Day-30 & & Day-1 & Day-15 \\
\hline Hemoglobin (g/L) & $128(123,135)$ & $131(125,140)$ & ns & $130(120,140)$ & $127(117,136)$ \\
\hline $\begin{array}{l}\text { Mean corpuscular } \\
\text { volume }(\mathrm{fL})\end{array}$ & $84.3(82.2,90.4)$ & $86.2(83.5,91.0)$ & ns & $86.4(82.0,92.0)$ & $85.4(82.2,90.5)$ \\
\hline Creatinine (mg/dL) & $1.0(0.9,1.1)$ & $0.9(0.85,1.1)$ & ns & $1.0(0.95,1.2)$ & $1.0(0.9,1.1)$ \\
\hline $\begin{array}{l}\text { Pl. vitamin B-12 } \\
\text { (pmol/L) }\end{array}$ & $92.8(71.0,117.6)$ & $122.1(90.6,141.3)$ & $<0.0001$ & $115.5(97.7,177.6)$ & $113.9(102.1,173.2)$ \\
\hline PI. folate (ng/mL) & $5.6(4.6,12.8)$ & $5.7(4.6,11.9)$ & ns & $6.1(4.4,13.8)$ & $5.9(4.2,14.9)$ \\
\hline PI. holo-TC (pmol/L) & $14.4(10.82,19.75)$ & $19.214 .95,24.6)$ & $<0.0001$ & $19.2(10.2,23.5)$ & $19.5(11.1,22.9)$ \\
\hline Pl. tHcy $(\mu \mathrm{mol} / \mathrm{L})$ & $31.9(22.6,54.0)$ & $24.9(18.54,41.45)$ & $<0.0001$ & $22.85(20.5,35.7)$ & $23.9(20.7,31.7)$ \\
\hline
\end{tabular}

p-values by Wilcoxon's Signed rank test, a non-parametric test for paired analysis ns- not significant. Median (25th, 75th \%le). 
Table 5 Effect of milk load $(600 \mathrm{ml})$ on plasma holo-TC concentrations

\begin{tabular}{|c|c|c|c|c|c|c|}
\hline & \multicolumn{2}{|l|}{ All $(n=51)$} & \multicolumn{2}{|c|}{ Normal group $(n=22)$} & \multicolumn{2}{|c|}{ Deficient group $(n=29)$} \\
\hline & Day-15 & Day-16 * & Day-15 & Day-16 N.S. & Day-15 & Day-16*** \\
\hline Plasma holo-TC concn. & 19.6 & 22.27 & 27.7 & 31.3 & 14.4 & 18.3 \\
\hline$(\mathrm{pmol} / \mathrm{L})$ & $(13.1,31.1)$ & $(16.6,35.8)$ & $(19.8,42.5)$ & $(21.6,46.1)$ & $(10.8,19.7)$ & $(13.7,25.2)$ \\
\hline
\end{tabular}

Values are Median $\left(25^{\text {th }}, 75^{\text {th }}\right.$ centile). $\mathrm{p}$-values by Wilcoxon's Signed rank test, a non- parametric test for paired analysis $\left({ }^{*} \mathrm{p}<0.01,{ }^{* * *} \mathrm{p}<0.0001\right.$, N.S.- not significant).

not change the strength of the association of milk load with holo-TC, vitamin B-12 and tHcy concentrations.

\section{Discussion}

The present study is to determine the beneficial effect of regular consumption of adequate milk on vitamin B-12 status in predominantly young vitamin B-12 deficient vegetarian Indians who had no folate deficiency. Milk was only found to be a significant contributor to vitamin B-12 intake in these participants.

Fifty seven percent of the participants had vitamin B-12 deficiency and 65\% had hyperhomocysteinemia, $84 \%$ had low plasma holo-TC ( $<35 \mathrm{pmol} / \mathrm{L})$ concentrations. However, none had any clinical (neurological/ anemia) symptoms of vitamin B-12 deficiency. They could be termed as subjects with Sub Clinical Cobalamin deficiency. One half of the participants with normal vitamin B-12 status (plasma vitamin B-12 >148 pmol/L and tHcy $<15 \mu \mathrm{mol} / \mathrm{L}$ ) had lower plasma holo-TC

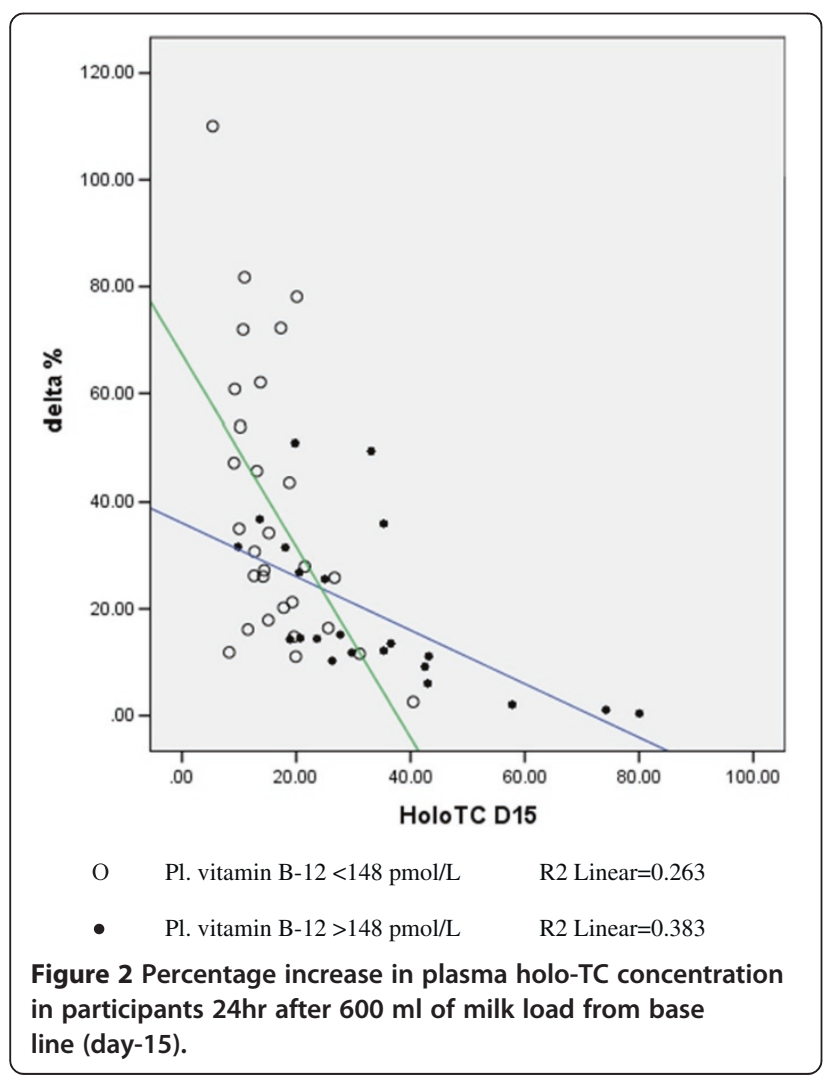

concentrations (median $27.7 \mathrm{pmol} / \mathrm{L}$ ) than normal white Caucasians $[5,6,29,30]$. The participants were consuming less than $1.4 \mu \mathrm{g}$ vitamin B-12 in daily diet. There was a significant association between dietary intake of vitamin B-12 and plasma vitamin B-12 and holo-TC concentrations which is in agreement with other studies $[5,7,29]$.

Holo-TC has a short half-life [31,32] and is therefore proposed to reflect recent vitamin B-12 absorption. Once in circulation, holo-TC is taken up into cells within minutes $[33,34]$. Until the cells are saturated with holo-TC, most of it is taken up so quickly that no large changes are observed initially in blood. Significant changes in the plasma holo-TC concentrations can be measured when the intake of vitamin B-12 is sufficient to saturate the cells with vitamin B-12. A dose dependent Holo-TC rise during $24 \mathrm{hrs}$ following vitamin B-12 administration suggested that the levels are influenced by recent absorption [15]. Plasma holo-TC concentration significantly increased $(0-120 \%, \mathrm{p}=0.0001)$ in vitamin B-12 deficient participants $24 \mathrm{hrs}$. following the milk load (Figure 2). Bhat et al [15] found a significant increase in plasma holo-TC concentration (0-150\%) $24 \mathrm{hrs}$ after loading with $6 \mu \mathrm{g}$ of cyanocobalamin in vitamin B-12 deficient subjects while Bor et al [35] found an increase $(0-108 \%)$ in normal subjects after $27 \mu \mathrm{g}$ load. Bor et al [35] and Castel-Roberts et al [36] reported that measuring the rise in plasma holo-TC concentration 24 hrs after vitamin B-12 load is better to assess recent intestinal absorption than measuring plasma vitamin B-12 alone. One fourth of the participants showed $<12.5 \%$ increase in holo-TC concentration after milk load. They may have mal-absorption or the ingested vitamin B-12 may have been used to saturate the cells. However, their plasma tHcy was reduced in vitamin B-12 deficient participants. These subjects need further evaluation for their gastrointestinal absorption status. Whereas, the participants with normal plasma B-12 concentration who did not show any increase in plasma holo-TC concentrations had basal level of $>45 \mathrm{pmol} / \mathrm{L}$ with $<12.5 \mu \mathrm{mol} / \mathrm{L}$ of plasma tHcy which implies that plasma holo-TC concentration reaches a plateau when basal plasma holo-TC concentration exceeds $45 \mathrm{pmol} / \mathrm{L}$ in vitamin B-12 deficients, similar to the observation by Bhat et al [15] who reported that plasma Holo-TC concentration increased from $10.6 \mathrm{pmol} / \mathrm{L}$ to 24.9 in adult Indian males and $30.5 \mathrm{pmol} / \mathrm{L}$ in females after ingesting 
Table 6 Plasma holo-TC increase considering the cutoff for holo-TC as $35 \mathrm{pmol} / \mathrm{L}$ (reference cutoff)

\begin{tabular}{|c|c|c|c|c|c|c|}
\hline \multirow[b]{2}{*}{ PI. holo-TC pmol/L } & \multicolumn{2}{|l|}{$\begin{array}{l}\text { All participants } \\
\mathrm{n}=51\end{array}$} & \multicolumn{2}{|c|}{$\begin{array}{l}\text { PI. holo-TC }>35 \mathrm{pmol} / \mathrm{L} \\
\text { (med vit B-12 } 267 \mathrm{pmol} / \mathrm{L} \text { ) } \\
\mathrm{n}=11\end{array}$} & \multicolumn{2}{|c|}{$\begin{array}{l}\text { PI. holo-TC }<35 \mathrm{pmol} / \mathrm{L} \\
\text { (med vit B-12 } 155 \mathrm{pmol} / \mathrm{L} \text { ) } \\
\mathrm{n}=40\end{array}$} \\
\hline & Day-15 & Day-16 P = 0.001 & Day-15 & Day-16 P = 0.013 & Day-15 & Day-16 P $<0.0001$ \\
\hline & $19.6(13.1,31.1)$ & $22.27(16.6,35.8)$ & $42.7(36.2,61.9)$ & $47.2(44.1,60.7)$ & $18.4(16.6,22.0)$ & $20.45(15.6,29.1)$ \\
\hline
\end{tabular}

Median $\left(25^{\text {th }}, 75^{\text {th }}\right.$ centile $)$.

p-compared to day-15 concentration.

$6 \mu \mathrm{g}$ of cyanocobalamin and 7.7 to 45.7 in males and 9.7 to $47.5 \mathrm{pmol} / \mathrm{L}$ in females after $30 \mu \mathrm{g}$ of cyanocobalamin ingestion.

Regular consumption of milk for 14 days increased the circulating concentration of vitamin B-12, holo-TC and decreased tHcy concentration in vitamin B-12 deficient participants indicating efficient metabolic effects (Table 4).

Carmel [37] categorized available biomarkers as those that directly measured plasma vitamin B-12 and those that measured metabolites that accumulated with inadequate amounts of vitamin B-12. Serum holo-TC and vitamin B-12 measured circulating vitamin B-12 concentrations. These two therefore reflected the broad vitamin B-12 status from high risk of severe deficiency to adequacy. Miller et al [38] stated that holo-TC and total vitamin B-12 have equal diagnostic accuracy in screening for metabolic vitamin B-12 deficiency. Measurement of both holo-TC and total vitamin B-12 provided a better screen for vitamin B-12 deficiency than either assay alone.

According to Green [39], low vitamin B-12 status was indicated by being below the lower the reference range (for vitamin B-12<148 pmol/L; for holo TC, <35 pmol/L), whereas for indirect measures of metabolites (methylmalonic acid or homocysteine), low vitamin B-12 status measures would be indicated by a level above the upper limit of the reference range (for methylmalonic acid, $>260 \mathrm{nmol} / \mathrm{L}$; for homocysteine, $>12 \mu \mathrm{mol} / \mathrm{L}$ ). The markers he mentioned were homocysteine for detection of either vitamin B-12 or folate deficiency and methylmalonic acid for vitamin B-12 deficiency only.

However, Valente et al [40] suggested a diagnostic strategy using holo-TC as the front-line test. The cutoffs for deficiency were defined as $20 \mathrm{pmol} / \mathrm{L}$ for holo-TC

Table 7 Plasma holo-TC increase considering the cutoff for holo-TC as median obtained in the present study (22.7 pmol/L)

\begin{tabular}{|c|c|c|c|}
\hline \multicolumn{2}{|c|}{$\begin{array}{l}\text { PI. holo-TC > 22.7pmol/L } \\
\text { (med vit B-12 } 280 \mathrm{pmol} / \mathrm{L} \text { ) } \\
\mathrm{n}=19\end{array}$} & \multicolumn{2}{|c|}{$\begin{array}{l}\mathrm{PI} . \text { holo-TC }<22.7 \mathrm{pmol} / \mathrm{L} \\
\text { (med vit B-12 } 139 \mathrm{pmol} / \mathrm{L} \text { ) } \\
\mathrm{n}=32\end{array}$} \\
\hline Day-15 & Day-16 P = 0.002 & Day-15 & Day-16 $P<0.0001$ \\
\hline $36.5(33.1,43.1)$ & $45.5(35.8,50.6)$ & $14.7(11.1,19.2)$ & $18.5(14.1,23.1)$ \\
\hline
\end{tabular}

median (25th, 75th centile).

p-compared to day-a5 concentration. and $123 \mathrm{pmol} / \mathrm{L}$ for serum vitamin B-12 after studying employees and medical students of a local hospital at Dundee, UK. We defined the participants as vitamin B-12 deficient who showed $<148 \mathrm{pmol} / \mathrm{L}$ of plasma vitamin B-12 concentration.

Yajnik et al [41] observed that the habitual intake of green leafy vegetables or other vegetables did not affect plasma vitamin B-12 or tHcy concentrations. They [41] have reported that the oral vitamin B-12 supplementation reduced plasma tHcy concentration in first two weeks but did not achieve normal plasma tHcy concentrations even after 6 wks. Deshmukh et al [42] studied the effects of physiological doses of oral vitamin B-12 on plasma tHcy and observed that the reduction was 5.5 and $6.8 \mu \mathrm{mol} / \mathrm{L}$ after 4 and 12 months of $2 \mu \mathrm{g}$ supplementation per day respectively, while supplementation of $10 \mathrm{ug}$ per day for 6 and 12 months reduced plasma tHcy concentration by 5.6 and $6.9 \mu \mathrm{mol} / \mathrm{L}$ respectively. There was no advantage in supplementing with higher dose. It has been observed in healthy adults that about $50 \%$ of a $1-\mu \mathrm{g}$ dose of vitamin B-12 is absorbed from food, while only $20 \%$ of a $5 \mu \mathrm{g}$ dose, and $5 \%$ of a $25 \mu \mathrm{g}$ dose is absorbed [43]. Therefore, intervention with at least 1.0 to $1.54 \mu \mathrm{g}$ of additional vitamin B-12 available from milk every day producing beneficial metabolic effect, increasing plasma vitamin B-12 and reducing tHcy, is advocated.

The novelty of the present study is that it used milk supplementation to measure both absorption capacity and efficiency to reduce plasma tHcy levels. Bor et al [35], von Castel-Roberts et al [36] and Bhat et al [15], used free cyanocobalamin to assess intestinal vitamin B-12 absorption while Deshmukh et al [43] used free cyanocobalamin for lowering plasma homocysteine levels. Although cyanocobalamin increases circulating levels of cobalamin, its ability to increase tissue levels of the active form of vitamin B-12 can be limited in a large number of subclinical and clinical conditions. The activation of cyanocobalamin to either adenosyl cobalamin or methyl cobalamin does not occur instantly, possibly occurring over 1-2 months [44] and requires decyanation, interaction of glutathione and in the case of methyl cobalamin, S-adenosyl methionine and the active form of folic acid. Qubeck study conducted on pigs showed that the intestinal absorption 
of vitamin B-12 from milk was higher than that of the synthetic form of vitamin B-12 by comparing the net fluxes of vitamin B-12 across the portal drained viscera after ingestion of milk or synthetic vitamin B-12 [45]. Vitamin B-12 in milk is in the form of coenzyme (adenosyl cobalamin), a major form in cellular tissues, where it is retained in the mitochondria, facilitating faster metabolic actions [46].

Even though the increase in plasma vitamin B-12 concentrations was modest $(29.6 \mathrm{pmol} / \mathrm{L})$ following milk intake by the participants, such an increase would be beneficial in vitamin B-12 deficient subjects. The increase in plasma holo-TC concentration after regular milk intake helped in lowering plasma tHcy concentrations (by $7 \mu \mathrm{mol} / \mathrm{L}$ ).

The limitation of the present study is that we have not measured plasma methylmalonic acid concentration which is a specific biomarker for vitamin B-12 deficiency status. The other marker, tHcy gets accumulated in both vitamin B-12 and folate deficiency. However, none of our participants had folate deficiency. The participants with $>148$ $\mathrm{pmol} / \mathrm{L}$ of plasma vitamin B-12 concentrations were not studied after 14 days consuming $400 \mathrm{ml}$ milk every day.

The recommended dietary allowance $(1 \mu \mathrm{g} /$ day $)$ for Indians seems to be inadequate. Even though there was significant reduction in plasma tHcy concentration 14 days after providing regular dietary vitamin B-12 (2.5 to $3 \mu \mathrm{g})$ in the form dairy products, the levels did not reach to normal levels. Effect of long term daily intake of milk on vitamin B-12 status should form a part of future study.

\section{Conclusions}

In conclusion, the present study reveals that dairy foods provide a highly bio-available source of vitamin B-12. Plasma holo-TC concentration increase 24 hrs after milk load can be a marker for dietary vitamin B-12 absorption ability. Adequate milk intake has the potential to increase circulating vitamin B-12 and holo-TC concentrations and reduce tHcy concentrations, a risk factor for cardiovascular disease. This study has implications for guidelines for the maintenance of normal vitamin B-12 status. Further study on large number of subjects with long term advice to consume adequate milk and observe the beneficial effects on health due to the improvement in vitamin B-12 status is needed. Then promotion of an adequate milk intake would be a good therapeutic strategy.

\section{Abbreviations \\ Holo-TC: Holotranscobalamin II; tHcy: Total homocysteine; mcv: Mean corpuscular volume.}

\section{Competing interests}

The authors declare that they have no competing interests.

\section{Authors' contributions}

Contributors: SSN was responsible for the study design, SSN, VB and AB had the primary responsibility to evaluate and write, NPM, SP and RT carried out the experimental work, the collection, analysis and statistical calculations regarding the blood tests. MK was responsible in statistical analysis. All authors read and approved the final manuscript.

\section{Authors' information}

Dr. Sadanand Naik: HOD (Clinical Biochemistry), Deenanath mangeshkar Hospital \& Research Centre, Pune.

M.Sc. Ph.D. (Med. Biochemistry): Important contribution in Nutrition (1) One of the group members who coined the term Thin Fat Indian Baby (2) Original contribution in Early life nutritional exposure (intra uterine and neonatal) play a prominent role in programming the susceptibility to chronic diseases, such as obesity, cardio vascular disease, diabetes mellitus, and osteoporosis. (3) Adiposity and Insulin Resistance originate from birth (Dr. C.S.Yajnik and group).

\section{Acknowledgements}

Abbott laboratories, IL, USA provided the free kits. Dr. Dhanajay Kelkar, the Medical Director, Deenanath Mangeshkar Hopsital, Pune, extended all the facilities to complete the study.

Mr. Charudatta Joglekar provided valuable help in preparing the manuscript. Mr. M.G.Sayyad extended help in statistical analysis.

\section{Author details}

${ }^{1}$ Department of Clinical Biochemistry \& Orthopedics, Deenanath Mangeshkar Hospital \& Research Centre, Erandvane, Pune, India. ${ }^{2}$ Department of Endocrinology, K.E.M. Hospital, Rasta Peth, Pune, India. ${ }^{3}$ Department of Biochemistry, Pune University, Ganesh Khind Road, Pune, India.

Received: 29 December 2012 Accepted: 2 October 2013

Published: 9 October 2013

\section{References}

1. Yates AA: Process and development of dietary reference intakes: basis, need and application of recommended dietary allowances. Nutr Rev 1998, 56:S5-S9.

2. Gopalan C, Rama Sastri BV, Balsubramanian SC, NarasingaRao BS, Deosthale YG, Pant KC: Nutritive value of Indian foods. Hyderabad: National Institute of Nutrition; 2007:98.

3. Food and Nutrition Board: Institute of Medicine. National Academy of Sciences, Subcommittee on Folate, Other B vitamins, and Choline, Dietary references intakes: thiamin, riboflavin, niacin, vitamin B-6, folate, vitamin B-12, pantothenic acid, biotin and choline. Washington DC: Natioanal Academy Press; 1998.

4. Howard JM, Azen C, Jacobsen DW, Green R, Carmel R: Dietary intake of cobalamin in elderly people who have abnormal serum cobalamin, methyl malonic acid and homocysteine levels. Eur J Clin Nutr 1998, 52:582-587.

5. Tucker KL, Rich S, Rosenberg I, Jacques P, Dallal G, Wilson PW, Selhub J: Plasma vitamin B-12 concentrations relate to intake source in the Framingham Offsprings study. Am J ClinNutr 2000, 71(2):514-522.

6. Bor MV, Lydeking-Olsen E, Moller J, Nexo E: A daily intake of $6 \mu \mathrm{g}$ vitamin B-12 appears to saturate all the vitamin B-12 related variables in Danish postmenopausal women. Am J ClinNutr 2006, 83:52-58.

7. Vogiatzoglou A, Smith AD, Nurk E, Berstad P, Drevon CA, Ueland PM, Vollset SE, Tell GS, Refsum H: Dietary sources of vitamin B-12 and their association with plasma vitamin B-12 concentrations in the general population: the Hordaland Homocysteine Study. Am J Clin Nutr 2009, 89:1078-1087.

8. Wokes F, Badenoch J, Sinclair HM: Human dietary deficiency of vitamin B-12. Am J Clin Nutr 1955, 3:375-382.

9. Dhopeswarkar GA, Trivedi JC, Kulkarni BS, Satoskar RS, Lewis RD: The effect of vegetarianism and antibiotics upon proteins and vitamin B-12 in the blood. Br J Nutr 1956, 10:105-110.

10. Antony AC: Vegetarianism and vitamin B-12 deficiency. Am J Clin Nutr 2003, 78:3-6.

11. Jathar VS, Patrawalla SP, Doonjagi DR, Rege DV, Satoskar RS: Serum vitamin B-12 levels in Indian psychiatric patients. Brit J Psychiatr 1970, 117:699-704.

12. Jathar VS, Inamdar-Deshmukh AB, Rege DV, Satoskar RS: Vitamin B-12 and vegetarianism in India. Acta Haematol 1975, 53:90-97.

13. Yajnik CS, Deshpande SS, Jackson AA, Refsum H, Rao S, Fisher DJ, Bhat DS, Naik SS, Coyaji KJ, Joglekar CV, Joshi N, Lubree HG, Deshpande VU, Rege SS, Fall CHD: Vitamin B-12 and folate concentrations during pregnancy and insulin resistance in the offspring: the pune maternal study. Diabetologia 2008, 51:29-38. 
14. Refsum H, Yajnik CS, Gadkari MA, Schneede J, Vollset SE, Oming L, Guttormsen AB, Joglekar A, Sayyad MG, Ulvik A, Ueland PM: Hyperhomocysteinemia and elevated methylmalonic acid indicate a high prevalence of cobalamin deficiency in Asian Indians. Am J Clin Nutr 2001, 74:233-241.

15. Bhat DS, Thuse NV, Lubree HG, Joglekar CV, Naik SS, Ramdas LV, Johnston C, Refsum H, Fall CH, Yajnik CS: Increases in plasma holotranscobalamin can be used to assess vitamin B-12 absorption in individuals with low plasma vitamin B-12. J Nutr 2009, 139:2119-2123.

16. Refsum H: Folate, vitamin B-12 and homocysteine in relation to birth defects and pregnancy outcome. Br J Nutr 2001, 85(Suppl 2):S109-S113.

17. Obeid R, Geisel J, Schorr T, Hubner U, Herrmann W: The impact of vegetarianism on some haematological parameters. Eu J Haematol 2002, 69:275-279.

18. Louman MW, van Dusseldrop M, Van de Vijver FS, Thomas CM, Schneede J, Ueland PM, Refsum H, van Staveren WA: Signs of impaired cognitive function in adolescents with marginal cobalamin status. Am J Clin Nutr 2000, 72:762-769.

19. Bhate V, Deshpande S, Bhat D, Joshi N, Ladkat R, Watve S, Fall C, de Jager CA, Refsum H, Yajnik CS: Vitamin B-12 status of pregnant Indian women and cognitive function in their 9 year-old children. Food Nutr Bull 2008, 29:249-254.

20. Brady J, Wilson L, McGregor L, Valente E, Orning L: Active B-12; a rapid, automated assay for holotranscobalamin on Abbott AxSYM analyser. Clin Chem 2008, 54:567-573.

21. Bartels H, Bohmer M: Microdetermination of creatinine. Clin Chim Acta 1971, 32:81-85.

22. Kanade AN, Rao S, Kelkar RS, Gupte S: Maternal Nutrition and birth size among urban affluent and rural women in India. A m J Clin Nutr. 2008, 27:137-145.

23. Gopalan C, Rama Sastri BV, Balsubraminian SC: Dietsoft soft-ware version 1.1.7 [developed by invincible, IDeAS, Nutritive value of Indian foods, Revised ed. Hyderabad: NIN, ICMR; 2007. www.invincibleideas.com.

24. Yajnik CS, Deshpande SS, Lubree HG, Naik SS, Bhat DS, Uradey BS, Deshpande JA, Rege SS, Refsum H, Yudkin J: Vitamin B-12 deficiency and hyperhomocysteinemia in Rural and Urban Indians. J Ass Phys India 2006 54:1-8.

25. Refsum H, Smith AD, Ueland PM, Nexo E, Clarke R, McPartlin J, Johnston C, Engbaek F, Schneede J, McPartlin C, Scott JM: Facts and recommendations about total homocysteine determinations: an expert opinion. Clin Chem 2004, 50:3-32.

26. Kwang-Sook W, Kyung-Eun $K$, Joon-Seok $P$, Joo-In P, Jin-Yeong H: Relationship between the levels of holotranscobalamin and vitamin B-12. Korean J Lab Med 2010, 30:185-189.

27. World Health Organization Nutritional anemia: Report of a WHO scientific group, WHO technical report series 405. Geneva: WHO; 1968:5-37.

28. Indian Council of Medical Research: Nutrient requirements and recommended dietary allowances for Indians, A report of the expert group of ICMR; 1990.

29. Lloyd-Wright Z, Hvas AM, Moller J, Sanders TA, Nexo E: Holotranscobalamin as an indicator of dietary vitamin B-12 deficiency. Clin Chem 2003, 49:2076-2078

30. Nexo E, Hoffmann-Lucke E: Holotranscobalamin, a marker of vitamin B-12 status: analytical aspects and clinical utility. Am J Clin Nutr 2011, 94(1):359S-365S

31. Hom BL, Olesen HA: Plasma clearance of 57 cobalt labelled vitamin B-12 bound in vitro and in vivo to transcobalamin I and II. Scand J Clin Lab Invest 1969, 23:201-211.

32. Schneider RJ, Burger RL, Mehlman CS, Allen RH: The role and rate of rabbit and human transcobalamin II in the plasma transport of vitamin B-12 in the rabbit. J Clin Invest 1976, 57:27-38.

33. Nexo E, Gimsing P: Turnover in humans of iodine and cobalamin labelled transcobalamin I and of iodine-labeled albumin. Scand J Lab Invest 1975, 35:391-398.

34. Herrmann W, Obeid R, Schorr H, Geisel J: The usefulness of holotranscobalamin in predicting vitamin B-12 status in different clinical settings. Curr Drug Metab 2005, 6:47-53.

35. Bor MV, von Castel-Roberts KM, Kauwell GP, Stabler SP, Allen RH, Maneval DR, Bailey LB, Nexo E: Daily intake of 4-7 $\mu$ g dietary vitamin B-12 is associated with steady concentrations of vitamin B-12 related biomarkers in a healthy young population. Am J Clin Nutr 2010, 91:521-527.

36. von C-R, Morkbak AL, Nexo E, Edgemon CA, Maneval DR, Shuster JJ, Valentine JF, Kauwell GPA, Bailey LB: Holotranscobalamin is an indicator of vitamin B-12 absorption in healthy adults with adequate vitamin B-12 status. Am J Clin Nutr 2007, 85:1057-1061.

37. Carmel R: Biomarkers of cobalamin (vitamin B-12) status in the epidemiologic applications: a critical over view of context, applications, and performance characteristics of cobalamin, methylmalonic acid and holotranscobalamin II. Am J Clin Nutr 2011, 94:348S-358S.

38. Miller JW, Garrod MG, Rockwood AL, Kushnir MM, Allen LH, Haan MN, Green R: Measurement of both total vitamin B-12 and holtranscobalamin singly and in combination in screening for metabolic vitamin B-12 deficiency. Clin Chem 2006, 52(2):278-285.

39. Green R: Indicators for assessing folate and vitamin B-12 status and for monitoring the efficiency of intervention strategies. Am J Clin Nutr 2011 94(2):666S-672S.

40. Valente E, Scott JM, Ueland PM, Cunningham C, Casey M, Molloy AM: Diagnostic accuracy of holotranscobalamin. Methylmalonic acid, serum cobalamin, and other indicators of tissue vitamin B-12 status in the elderly. Clin Chem 2011, 57(6):856-863.

41. Yajnik CS, Lubree HG, Thuse NV, Ramdas LV, Deshpande SS, Deshpande VU, Deshpande JA, Uraday BS, Ganpule AA, Naik SS, Joshi NP, Farrant H, Refsum $\mathrm{H}$ : Oral vitamin B-12 reduces total homocysteine concentration in women in India. Asia Pac J Clin Nutr 2007, 16(1):103-109.

42. Deshmukh US, Joglekar CV, Lubree HG, Ramdas LV, Bhat DS, Naik SS, Hardikar PS, Raut DA, Konde TB, Wills AK, Jackson AA, Refsum H, Nanivadekar AJ, Fall CH, Yajnik CS: Effect of physiological doses of oral vitamin B-12 on plasma homocysteine: a randomized, placebo-controlled, double blind trial in India. Eur J ClinNutr 2010, 64:495-502.

43. Kelly G: The coenzyme forms of vitamin B-12: Toward an understanding of their therapeutic potential. Altern Med Rev 1997, 2:459-471.

44. Pezacka E, Green R, Jacobsen DW: Glutathionylcobalamin as an intermediate in the formation of cobalamin coenzymes. Biochem Biophys Res Comm 1990, 169:443-450.

45. Matte JJ, Guay CL, Girard CL: Milk, an outstanding source of vitamin B-12. JWCDS Adv Dairy Technol 2011, 23:390.

46. Matte JJ, Guay F, Girard CL: Bioavailability of vitamin B-12 in cow's milk. Br J Nutr 2012, 107(1):61-66.

doi:10.1186/1475-2891-12-136

Cite this article as: Naik et al:: Daily milk intake improves vitamin B-12 status in young vegetarian Indians: an intervention trial. Nutrition Journal 2013 12:136

\section{Submit your next manuscript to BioMed Central and take full advantage of:}

- Convenient online submission

- Thorough peer review

- No space constraints or color figure charges

- Immediate publication on acceptance

- Inclusion in PubMed, CAS, Scopus and Google Scholar

- Research which is freely available for redistribution 